\title{
Growth, mortality and exploitation rate of Pampus argenteus, Parastromateus niger and Scomberomorus commerson in Sebatik Waters, Indonesia
}

\author{
GAZALI SALIM $^{1, \bullet}$, KUN RETNO HANDAYANI ${ }^{2}$, AGUS INDARJO ${ }^{3}$, JULIAN RANSANGAN ${ }^{4}$, \\ NURUL ATIEQAH ${ }^{1}$ \\ ${ }^{1}$ Department of Aquatic Resource Management, Faculty of Fisheries and Marine Science, Universitas Borneo Tarakan. Jl. Amal Lama No. 1, Tarakan \\ 77115, North Kalimantan, Indonesia. Tel./fax.: +62-551-2052558, `email: axza_oke@yahoo.com \\ ${ }^{2}$ Representative of Central Java Province, Ombudsman of the Republic of Indonesia. Jl. Siwalan No. 5, Wonodri, Semarang 50242, Central Java, \\ Indonesia \\ ${ }^{3}$ Department of Marine Science, Faculty of Fisheries and Marine Science, Universitas Diponegoro. Jl. Prof. H. Soedarto, S.H, Tembalang, Semarang \\ 50275, Central Java, Indonesia \\ ${ }^{4}$ Borneo Marine Research Institute, University of Malaysia Sabah. 88400 Kota Kinabalu, Sabah, Malaysia
}

Manuscript received: 16 September 2020. Revision accepted: 24 October 2020.

\begin{abstract}
Salim G, Handayani KR, Indarjo A, Ransangan J, Atieqah N. 2020. Growth, mortality and exploitation rate of Pampus argenteus, Parastromateus niger and Scomberomorus commerson in Sebatik Waters, Indonesia. Biodiversitas 21: 5363-5372. The economic revenue of the local government of the Indonesian Sebatik Island relies much on the exploitation of its rich marine biodiversity. One of the important economic activities is the capture fisheries of commercially important fishes such as the white pomfret (Pampus argenteus) and black pomfret (Parastromateus niger), and mackerel fish (Scomberomorus commerson). The current study aims to estimate the growth, condition factor, and exploitation rate of the fish species for developing sustainable fishery management. Fish samplings were conducted in the Sebatik Waters, Nunukan District, North Kalimantan Province, Indonesia from June to July 2020. The fish were caught using gillnet at daytime (pomfrets) and nighttime (mackerel), respectively. Then, 82, 73, and 83 specimens of white pomfret, black pomfret, and mackerel were randomly selected for the length-weight relationship, condition factor, and exploitation rate analysis, respectively. The results revealed that the size distribution of the white pomfret population in the coastal waters of Sebatik Island ranged from 220.0 to 351.0 $\mathrm{mm}$, black pomfret ranged from 231.0 to $362.0 \mathrm{~mm}$ and mackerel, ranged from 242.0 to $432.0 \mathrm{~mm}$. All the fish species exhibited negative allometric $(b<3)$ weight and length relationship with moderate to strong correlation. About $50 \%$ and $53.42 \%$ of the white pomfrets and black pomfrets were characterized by thin body shape. However, $49.40 \%$ of the mackerels were characterized by fat body shape. The asymptotic length $(\mathrm{L} \infty)$ for white pomfrets was recorded at $359.133 \mathrm{~mm}$; $\mathrm{k}$ value of $0.0427 \mathrm{~mm} /$ year with $\mathrm{r}$-value of 0.9918 and the to value of $1.11 /$ year. For black pomfret, the $\mathrm{L}_{\infty}$ was estimated at $370.22 \mathrm{~mm}$; $\mathrm{k}$ value of $0.043 \mathrm{~mm} /$ year with $\mathrm{r}$-value at 0.9919 and the $\mathrm{t}_{0}$ value of $1.104 /$ year. For mackerel, the L $\infty$ value was estimated at $492.724 \mathrm{~mm}$, k-value of $0.0246 \mathrm{~mm} /$ year with r-value of 0.9634 , and the $\mathrm{t}_{0}$ value of 1.322/year. The total mortality, fishing mortality and natural mortality (Z, F, and N, respectively) and exploitation rate (E) for white fish were recorded at $113.76 \%, 80.58 \%, 33.18 \%$, and $70.83 \%$, respectively. For black pomfret, it recorded $113.15 \%(\mathrm{Z}), 79.97 \%(\mathrm{~F}), 32.75 \%$ $(\mathrm{N})$ and $70.67 \%(\mathrm{E})$. For mackerel, it recorded $109.87 \%(\mathrm{Z}), 66.29 \%(\mathrm{~F}), 43.58 \%(\mathrm{~N})$ and $60.33 \%(\mathrm{E})$. The high exploitation rate $(>50 \%)$ and fishing mortality $(>60 \%)$ of all the fish species analyzed in this study indicate that there is a sign of overfishing to these fish resources in the coastal waters of Sebatik island. Hence, sustainable fishing management is timely needed to prevent depletion of these important fishery resources. Such management can include fishing restrictions for small-sized and first mature fish, close fishing season, and strict requirement for fishing permits.
\end{abstract}

Keywords: Fisheries management, overfishing, population, population depletion

\section{INTRODUCTION}

Nunukan District is one of the districts located in the northern region of North Kalimantan Province, Indonesia. It is directly adjacent to Sabah, Malaysian Borneo and subdivided into several districts. Sari and Sujarwoto (2019) stated that the area of Nunukan District consists of 19 subdistricts in 2019. Nunukan District has one outer island, Sebatik Island. Sebatik Island is one of the 92 outermost small islands located in the North Kalimantan Province which directly adjacent to neighboring countries, namely Malaysia and Philippines. Sebatik Island is divided into two, the northern and the southern Sebatik Island. The northern part has belonged to Malaysia whereas the southern part-owns by the Nunukan District, Indonesia. In term of area, the Malaysian Sebatik Island covers 187.23 $\mathrm{km}^{2}$ while the Indonesian Sebatik Island has a coverage $246.61 \mathrm{~km}^{2}$ (Pemerintah Kabupaten Nunukan, 2002).

The economic potential of the Indonesian Sebatik Island relies on its rich marine resources. Capture fishery is the main economic activity of the community on that island. This activity contributed about 302,356.58 tons of fish to the Nunukan District in 2016 (BPS Kabupaten Nunukan, 2017). Major part of this production is exported to neighboring countries, particularly Malaysia. The main targets of this capture fishery in Sebatik Island are the white pomfret (Pampus argenteus) and black pomfret (Parastromateus niger). However, other bycatches such as 
grouper (Epinephelus spp), trevally fish (Caranx spp), red snapper (Lutjanus spp), sea catfish (Arius thalassinus), and mackerel (Rastreliger sp.) (Khaerudin, 2006) are also quite significant. Many of the targets species are demersal fish (e.g. white pomfret and black pomfret) which often live and feed on at the bottom of the water or in the water column near the coast to the depth of $100 \mathrm{~m}$ (Prihatiningsih et al. 2015; Hikmawansyah et al. 2019; Nugraeni et al. 2019). In addition to demersal fish, mackerel (Scomberomorus commerson), a large pelagic fish belonging to the Scombridae family (Randall, 1995) is also targeted for gill net fishing in the island.

From an economic viewpoint, pomfrets are highly demanded fish and have attractive prices. For example, the price for white (P. argenteus) is around Rp. $150,000.00 / \mathrm{kg}$ or USD10.18/kg while black pomfret fish (Ps. niger) is slightly lower at Rp. $100,000 / \mathrm{kg}$ or USD6.79/kg (Prihatiningsih et al. 2015). Mackerel (S. commerson) also has a good price at Rp. $60,000 / \mathrm{kg}$ or USD4.07/kg (Noegroho et al. 2018). Generally, frozen pomfret fish are exported to China, Korea, Japan, Malaysia (Nugraeni et al. 2019), Singapore and Thailand. Black pomfret (Ps. niger) is also quite expensive at Rp. $140,000 / \mathrm{kg}$ but this fish is rarely caught in the Indonesian Sebatik Island. Because of high demand and attractive prices, these fish resources often became the target for unsustainable fishing activity. Hence, sustainable management of these fishery resources is needed.

Unlike in Kuwait (Morgan et al. 1985), China (Shu and Qiu 2005), Bangladesh (Mustafa 1993; Mustafa 1999), Iran (Alit 2001; Mohamed et al. 2008; Narges et al. 2011; Hashemi et al. 2012, Iraq (Nukpi 1996; Salari 1996; Parsamanesh et al. 2003; Mohamadi et al. 2005), Korea (Lee and Kim 1992), Tarakan Waters (Prihatiningsih et al. 2015; Laga et al. 2017), Oman Sea (Parsa et al. 2017), In Pangandaran Waters (Hikmawansyah et al. 2019), in Paloh Waters in West Kalimantan (Damora et al. 2018), the growth characteristics of pomfret fish in the Indonesian Sebatik Island are yet to be studied.

Therefore, the present study was conducted to analyze the levels of fish mortalities, exploitations, and growth characteristics of white pomfret ( $P$. argenteus), black pomfret fish ( $P$ s. niger), and mackerel ( $S$. commerson) in the coastal waters of Sebatik Island, North Kalimantan, Indonesia.

\section{MATERIALS AND METHODS}

\section{Sampling site}

This study analyzed fish specimens of three different species, namely white pomfret, black pomfret, and mackerel which were obtained from fishermen's catch in the Sebatik Waters, Nunukan District, North Kalimantan Province, Indonesia. Samplings were conducted 4 times (June $13^{\text {th }}$, June $26^{\text {th }}$, July $17^{\text {th }}$, and July $30^{\text {th }}$ ) during the 2 months sampling period starting June 2020 to July 2020 following the purposive sampling method following Prasetiyo et al. (2020). The samplings were done at the two predetermined fishing grounds around the Indonesian Sebatik Island using gillnets (Figure 1). The two fishing grounds are the waters within Tanjung Harapan to Batulamampu $\left(4^{0} 9^{\prime} 23^{\prime \prime} \mathrm{N} ; 117^{0} 57^{\prime} 55^{\prime \prime} \mathrm{E}\right)$ and the waters within Taiwan River to Cape Aru (4 $\left.2^{\prime} 64^{\prime \prime} \mathrm{N} ; 117^{0} 64^{\prime} 48^{\prime \prime} \mathrm{E}\right)$. The samplings for pomfrets were done during daytime whereas samplings for mackerels were carried out at night.

\section{Data collection}

Throughout the sampling period, 82, 73, and 83 individuals of white pomfret, black pomfret, and mackerel (Figure 2) were randomly selected from the fishermen catches for analyses. Then, the total length and total weight of each fish specimen were measured by using the measuring tape and electric balance, respectively. After that, the length sizes were distributed into 10 size classes.

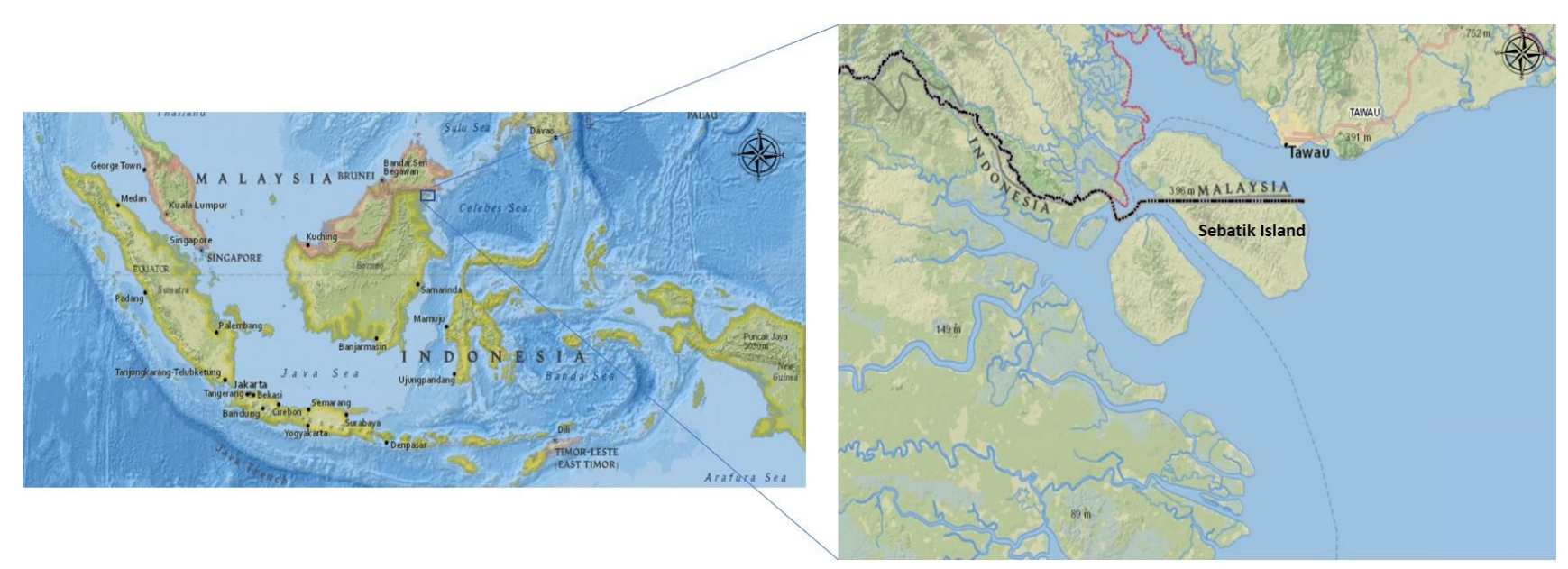

Figure 1. Study site in map of Indonesia (left); Sebatik Island (right) 


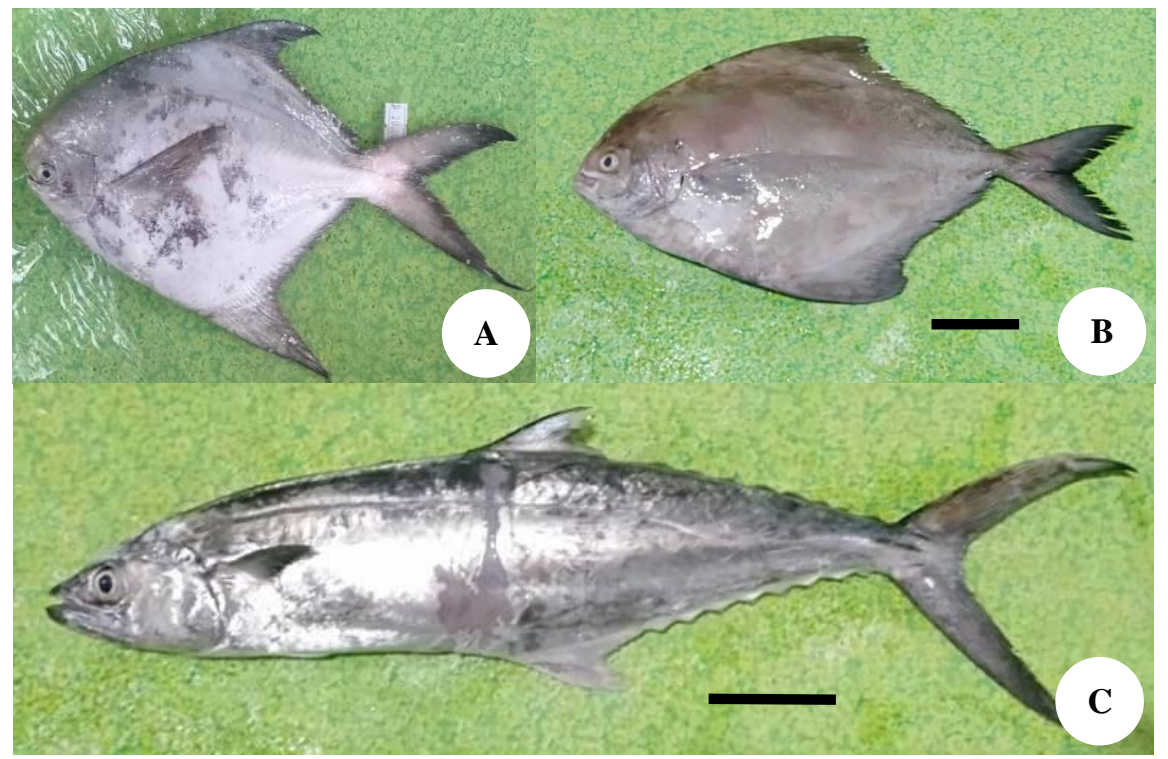

Figure 2. Specimens collected from fishermen operating in the coastal water of Sebatik Island, Indonesia. A. white pomfret $(P$. argenteus); B. Black pomfret (Ps. niger); C. Mackerel (S. commerson). Bar $=5 \mathrm{~cm}$

\section{Data analysis}

\section{Length-weight relationship}

The length-weight relationship was calculated by the allometric growth formula as used by Ricker (1973) as follows:

$$
\mathrm{W}=\mathrm{aL}^{\mathrm{b}}
$$

Where, W: stands for weight; L: length; a: is a constant; b: the exponent.

The equation was transformed into a logarithmic as suggested by Le Cren (1951) and expressed as:

$$
\log W=\log a+b \log L
$$

Where, a: constant being initial growth; b: growth coefficient. The values ' $a$ ' and ' $b$ ' were determined empirically.

\section{Condition factor and Relative condition factor}

Condition factor of Ponderal index (K) each fish species were also determined by using the following formula:

$$
K=10^{5} x \frac{w}{L^{3}}
$$

Where, K: condition factor; W: mean weight of fish $(\mathrm{g})$; $\mathrm{L}$ : mean length of fish $(\mathrm{mm})$; the number $10^{5}$ is the factor to bring the Ponderal index $(\mathrm{K})$ near to unity (Walker and Carlander 1970).

Relative condition factor ' $\mathrm{Kn}$ ' introduced by Le Cren (1951) was estimated by the following formula:

$$
\mathrm{Kn}=\frac{W}{W}
$$

Where, W: actual weight of fish $(\mathrm{g})$; $\hat{\mathrm{W}}$ : expected weight of fish in gram $(\mathrm{g})$. The $\hat{\mathrm{W}}$ was estimated from the logarithmic transformed of the allometric growth formula:

$\log W=\log a+b \log L$

The condition index was then compared with the index suggested by Firdaus and Salim (2011), Salim (2013, 2015), Firdaus et al. (2018, 2020), and Indarjo et al. (2020).

\section{Estimation of absolute growth using Von Bertalanffy's Model}

Absolute growth of the fish species was measured by using the Von Bertalanffy growth function (Sparre and Venema 1998) as follows:

$$
\mathrm{L}(\mathrm{t})=\mathrm{L} \infty\left(1-\mathrm{e}-\mathrm{k}\left(\mathrm{t}-\mathrm{t}_{0}\right)\right)
$$

Where, $\mathrm{L}(\mathrm{t})$ : length of fish at age $\mathrm{t}$ (unit of time); L $\infty$ : the maximum length of fish (length asymptotic); K: fish growth coefficient (per unit time); $\mathrm{t}_{0}$ : fish theoretical age at zero length.

The variable age structure was estimated using the mode class shift method associated with the Von Bertalanffy growth function (Sparre and Venema 1998) as follows:

$$
\begin{aligned}
& (\Delta \mathrm{L} / \Delta \mathrm{t})=(\mathrm{L} 2-\mathrm{L} 1) /(\mathrm{t} 2-\mathrm{t} 1) \\
& \mathrm{L}(\mathrm{t})=(\mathrm{L} 2+\mathrm{L} 1)
\end{aligned}
$$

Where, $\Delta \mathrm{L} / \Delta \mathrm{t}$ : relative growth of fish; $\Delta \mathrm{L}$ : fish length; $\Delta \mathrm{t}$ : time difference for taking fish samples; $\mathrm{L}(\mathrm{t})$ : average length of the mode.

The linear equation, $\mathrm{Y}=\mathrm{a}+\mathrm{bx}$ of the age structure was established by plotting the values of $\mathrm{L}(\mathrm{t})$ and $(\Delta \mathrm{L} / \Delta \mathrm{t})$. 
Where, $\mathrm{a}=\left(\left(\sum \mathrm{y} / \mathrm{n}\right)-\left(\mathrm{b}\left(\sum \mathrm{x} / \mathrm{n}\right)\right)\right) ; \mathrm{b}=\left(\mathrm{n} \sum(\mathrm{xy})-\left(\sum \mathrm{x}\right)\right.$ $\left.\left(\sum \mathrm{y}\right)\right) /\left(\mathrm{n} \sum \mathrm{x} 2-\left(\sum \mathrm{x}\right) 2\right)$

The average length value of the long mode uses the linear regression equation method to calculate the asymptotic length $(\mathrm{L} \infty)$ of the fish, namely $-\mathrm{a} / \mathrm{b}$, while the growth coefficient $(\mathrm{K})$ is $-\mathrm{b}$. The theoretical age of fish when the length is equal to zero was estimated separately using the empirical equation (Sparee and Venema 1998):

$$
\log _{10}\left(-\mathrm{t}_{0}\right)=-0.3922-0.275 \log _{10} \mathrm{~L} \infty-1.038 \log _{10} \mathrm{~K}
$$

Where, L $\infty$ : asymptotic length of fish (mm); K: fish growth rate coefficient; $t_{0}$ : theoretical age of fish at length equal to zero (year).

\section{Estimation of mortality and exploitation level}

The natural mortality (M) of the fish species was estimated using Pauly's empirical formula (Pauly 1984):

$\log _{10} \mathrm{M}=-0.0066-0.279 \log _{10} \mathrm{~L} \infty+0.6543 \log _{10} \mathrm{~K}+$ $0.4634 \log _{10} \mathrm{~T}$

Where, M: natural mortality; L $\infty$ : asymptotic length; K: growth coefficient; $\mathrm{T}$ : average surface temperature of the water.

Total mortality $(Z)$ of the fish species was estimated using the Beverton and Holt's Z-equation (Sparre and Venema 1998; Sparre and Venema 1998):

$$
\mathrm{Z}=\mathrm{K} \cdot\left[\frac{\mathrm{L}_{\infty}-\bar{L}}{\bar{L}-L^{\prime}}\right]
$$

Fishing mortality (F) of the fish was calculated by subtracting total mortality (Z) with natural mortality (M) as follows:

$$
\mathrm{F}=\mathrm{Z}-\mathrm{M}
$$

According to Pauly (1984), rate of exploitation (E) is ratio of fishing mortality $(\mathrm{F})$ and total mortality $(\mathrm{Z})$, and can be written as:

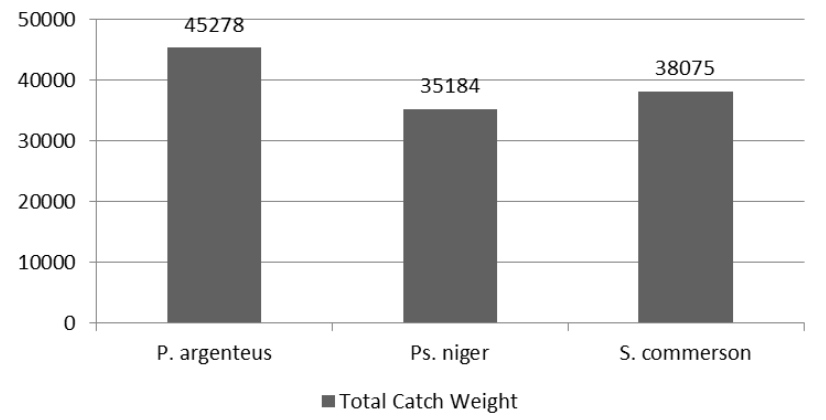

A

$$
E=\frac{F}{F+M}=\frac{F}{Z}
$$

\section{RESULTS AND DISCUSSION}

\section{Size structure}

During the 2 months survey, it was noted that fishermen operating in the coastal waters of the Indonesian region of Sebatik Island were recorded able to capture 45,278 tons (38.2\%) of white pomfret, 35,184 tons $(29.68 \%)$ of black pomfret and 38,075 tons (32.12\%) of mackerel (Figure 3). Out of these catches, 82 specimens of white pomfret $(34.45 \%), 73$ specimens of black pomfret $(30.67 \%)$ and 83 specimens $(34.87 \%)$ of mackerel were randomly collected (Figure 4) for size (length) distribution analysis, growth characteristics, estimation of fish mortalities and level of exploitation. The results indicated that the length distribution of the three fish species was narrow and concentrated within the 260 to $341 \mathrm{~mm}$ (Figure 5).

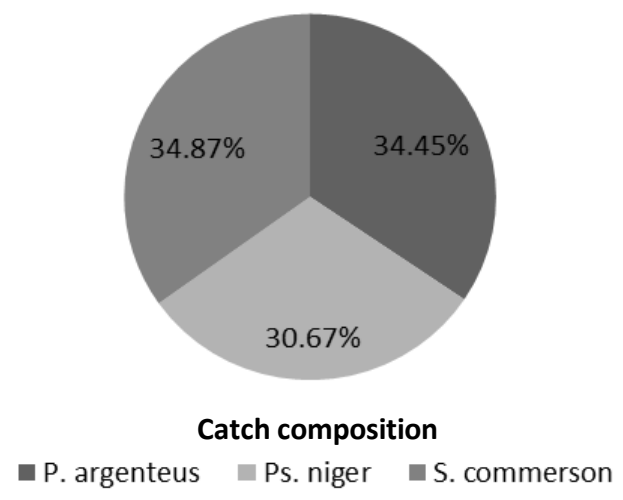

Figure 4. Percentage of fish specimens used for growth, mortalities and level of exploitation rate analyses

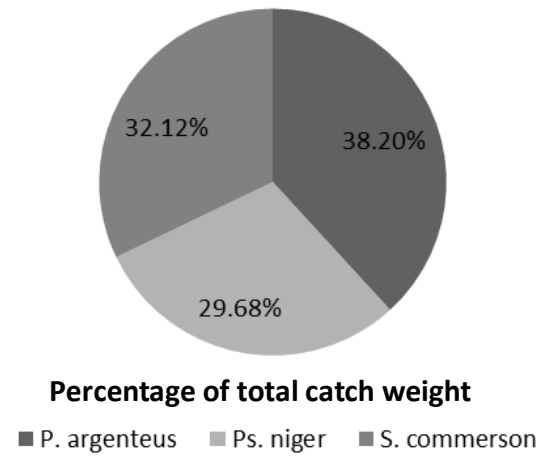

B

Figure 3 Total catch weight (A) and percentage of total catch weight (B) of each fish species caught in the coastal waters of the Indonesian region of Sebatik Island during the two months sampling period 


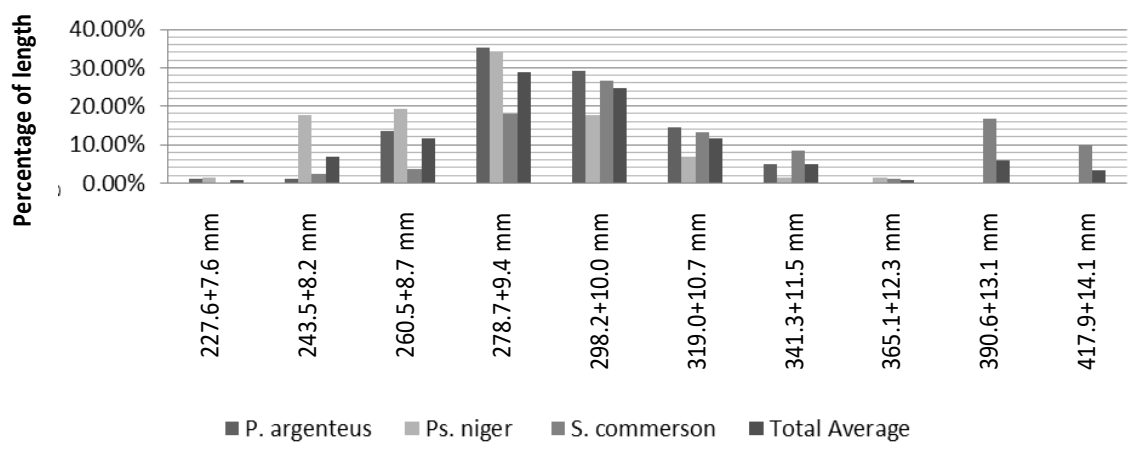

Figure 5. Percentage of length distribution of fish specimens (P. argenteus, Ps. niger and S. commerson) occurring in the coastal waters of the Indonesian region of Sebatik Island during sampling period

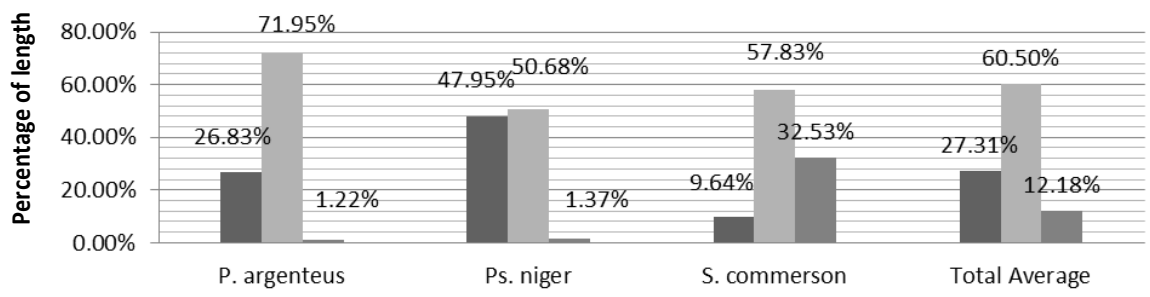

$=249.2+7.2 \mathrm{~mm}$ (Small Length) $=264.0+7.6 \mathrm{~mm}$ (Medium Length) $=279.8+8.1 \mathrm{~mm}$ (Large Length)

Figure 6. Percentage of size (length) distribution of the fish specimens (P. argenteus, Ps. niger and S. commerson) caught in the coastal waters of the Indonesian region of Sebatik Island, Indonesia

The white pomfret specimens were distributed within the size classes $220.0-351.0 \mathrm{~mm}(285.5 \pm 65.5 \mathrm{~mm} ; \mathrm{n}=82)$. However, the dominant size class was within the 277.9$291.1 \mathrm{~mm}(284.5 \pm 6.6 \mathrm{~mm})$ at $30.5 \%$. Small portion $(1.22 \%)$ of the fish specimens were felt within the 220 $241.4 \mathrm{~mm}$ and $335-351 \mathrm{~mm}$ size class. As for black pomfret, they have distributed within the $231.0-362.0 \mathrm{~mm}$ $(296.5 \pm 65.5 \mathrm{~mm} ; \mathrm{n}=73)$ size classes. Similar to black pomfret, the dominant size was within the $276.5-289.1 \mathrm{~mm}$ $(282.8 \pm 6.3 \mathrm{~mm})$ at $24.7 \%$ but small amount of the black pomfret specimens $(1.37 \%)$ were categorized within the $330.0-362.0 \mathrm{~mm} \quad(346.4 \pm 15.6 \mathrm{~mm})$ size classes, respectively. According to Prihatiningsih et al. (2015), the size distribution of white pomfret in Tarakan city ranged from 90-350 $\mathrm{mm}$ (average 179.3 $\pm 180 \mathrm{~mm}$; $\mathrm{n}=1255$ ). According to Parsa et al. (2017), the size distribution of white pomfret $(P$. argenteus) in Iranian Waters ranged between 100 and $320 \mathrm{~mm}(199.7 \pm 1.2 \mathrm{~mm} ; \mathrm{n}=1919)$. Whereas the size distribution of white pomfret in Khuzestan Province (northwest the Persian Gulf) was recorded between 95 and $312 \mathrm{~mm}$ (Narges et al. 2011). Mohammadkhani and Shirangi (2013) reported the size distribution of $P$. argenteus in Oman Sea to range from 150 to $350 \mathrm{~mm}$. Hikmawansyah et al. (2019) also reported that the size distribution of white pomfret in Pangandaran Waters to range between 193 and $368 \mathrm{~mm}$. Damora et al.
(2018) reported the size distribution for P. argenteus in Paloh Waters, West Kalimantan was from 120 to $450 \mathrm{~mm}$. Thus, the size distribution of the white pomfret in Sebatik island is within the range and agreed to the records obtained elsewhere.

The mackerel fish in Sebatik island ranged from 242.0 to $432.0 \mathrm{~mm}(337.0 \pm 95 \mathrm{~mm} ; \mathrm{n}=83)$. The majority $(21.69 \%)$ of the fish specimens were felt under the 287.9-305.0 $(296.5 \pm 8.5 \mathrm{~mm})$ size class. However, small portion of the fish $(2.41 \%)$ were in the $256.4-271.6 \mathrm{~mm}(264.0 \pm 7.6 \mathrm{~mm})$ size class. According to Noegroho et al. (2018), the size distribution of mackerel fish in Kwandang Bay, Sulawesi Sea was recorded to range from 250 and $1380 \mathrm{~mm}$ $(\mathrm{n}=5248)$.

It is obvious in the present study that the size distribution of the three fish species important to fishery sector in Sebatik Island was categorized into three size classes (Figure 6) which are small $(249.2 \pm 7.2 \mathrm{~mm})$, medium $(264.0 \pm 7.6 \mathrm{~mm})$, and large $(279.8 \pm 8.1 \mathrm{~mm})$. However, the dominant size class for white pomfret $(71.95 \%)$, black pomfret $(50.68 \%)$, and mackerel $(60.5 \%)$ was the medium size class. It is also interesting to note that small portion of the white pomfret $(1.22 \%)$, black pomfret $(1.37 \%)$, and mackerel $(9.64 \%)$ were grouped within the large size class category $(279 \mathrm{~mm})$, respectively. 
Table 1. Allometric Growth and correlation

\begin{tabular}{lcccc}
\hline \multirow{2}{*}{ Sample of fish } & \multicolumn{4}{c}{ Allometric growth } \\
\cline { 2 - 5 } & $\begin{array}{c}\text { Number of } \\
\text { fish specimens }\end{array}$ & $\mathbf{b}$ & $\mathbf{r}^{\mathbf{2}}$ & $\mathbf{r}$ \\
\hline P. argenteus & 82 & 2.7303 & 0.2515 & 0.5015 \\
Ps. niger & 73 & 1.9697 & 0.197 & 0.444 \\
S. commerson & 83 & 0.6309 & 0.262 & 0.512 \\
\hline
\end{tabular}

\section{Allometric growth}

The present study revealed (Table 1) that the growth of the three fish species was described as negative allometric growth (value $\mathrm{b}<3$ ), with a strong correlation value for white pomfret $(\mathrm{r}=0.5015)$ and mackerel $(\mathrm{r}=0.512)$ but moderately for black pomfret $(r=0.444)$. According to Prihatiningsih et al. (2015), the exponential equation of the length-weight relationship of white pomfret in the waters of Tarakan was characterized as allometric negatively $(b=$ 2.374 and $r=0.916$ ). This is in agreement to Laga et al (2017) who suggested both male and female pomfrets exhibit negative allometric growth (male $b=0.334 ; \mathrm{r}=$ 0.962 and female $b=0.335 ; r=0.963$ ). Hikmawansyah et al. (2019) also reported negative allometric growth for the white pomfret in Pangandaran Waters $(b=2.371 ; r=$ 0.9332). For mackerel, the result of present study was contrary to the result of Weng et al. (2020) who reported a positive allometric growth with very strong correlation for mackerel fish in Central Taiwan Street $(b>3, r=0.754$; $n=$ 110). The differences in the level of correlation between length and weight in fish could be due to both internal (intrinsic) and external (extrinsic) factors which are generally difficult to control. The internal factors include sex, age, parasites, and diseases whereas the external factors include food (Mommsen 1998) and water temperature (Effendie 2002; Prihatiningsih et al. (2015); Indarjo et al. 2020). However, Ecoutin and Abaret (2005) and Hamid et al. (2015) did suggest that number of samples ( $<30$ specimens) and sampling procedure can also affect the $b$ values and length-weight relationships of fish species. In the present study, it is difficult to ascertain if the sampling influenced the $\mathrm{b}$ values and the correlation strength between length and weight. In addition, removal of fish specimens via overfishing may also affect this relationship.

\section{Condition index}

Analysis of condition index of the white pomfret revealed that the fish population consisted of 5 different body shapes namely very thin, thin, proportional, fat and very fat. This shows that the population of white pomfret in the coastal waters of Sebatik Island has a balanced distribution in terms of condition index (body shape). The same observation was noted for black pomfret, except it did not record fish with proportional body shape. As for mackerel, no specimens were noted within the thin body shape category. It also appears that the population of white pomfret $(50 \%)$ and black pomfret $(53.42 \%)$ in the coastal waters of Sebatik Island were dominated by fish specimens within the thin body shape category. For mackerel, $49.40 \%$ of the population was characterized by very fat (obese) body shape category (Figure 7). The observation on the condition index of white pomfret in waters of Sebatik island was different from Tarakan waters because the fish population in that area was dominated by very fat body shape category. The differences in the condition index of the fish analyzed in this study may be due to the availability of foods in the habitat and differences in gonad development among fish (Gupta et al. 2011).

\section{Von Bertalanffy's growth}

From Von Bertalanffy's growth model, the maximum length and the average growth rate of the three fish species were successfully estimated (Figure 8). It was estimated that the white pomfret can grow to maximum length of $L \infty$ $359.133 \mathrm{~mm}$ with a growth rate $(\mathrm{k})$ of $0.0427 \mathrm{~mm} /$ year with a correlation value of 0.9918 and a value $\left(\mathrm{t}_{0}\right)$ of 1.11 /year. Black pomfret fish obtained an L $\infty$ growth of $370.22 \mathrm{~mm}$ with a growth speed $(\mathrm{k})$ of $0.043 \mathrm{~mm} / \mathrm{year}$ with a correlation value of 0.9919 and a value $\left(\mathrm{t}_{0}\right)$ of $1.104 /$ year. Mackerel fish obtained an L $\infty$ growth of 492,724 mm with a growth speed $(\mathrm{k})$ of $0.0246 \mathrm{~mm} /$ year with a correlation value of 0.9634 and a value $\left(\mathrm{t}_{0}\right)=1.322 /$ year.

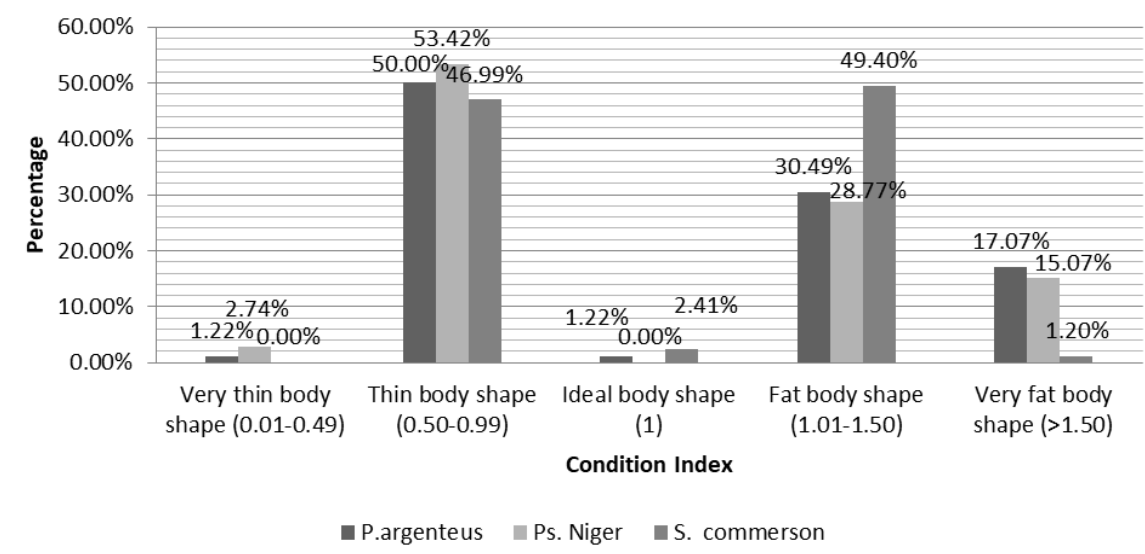

Figure 7. Percentage of fish specimens according to index condition 


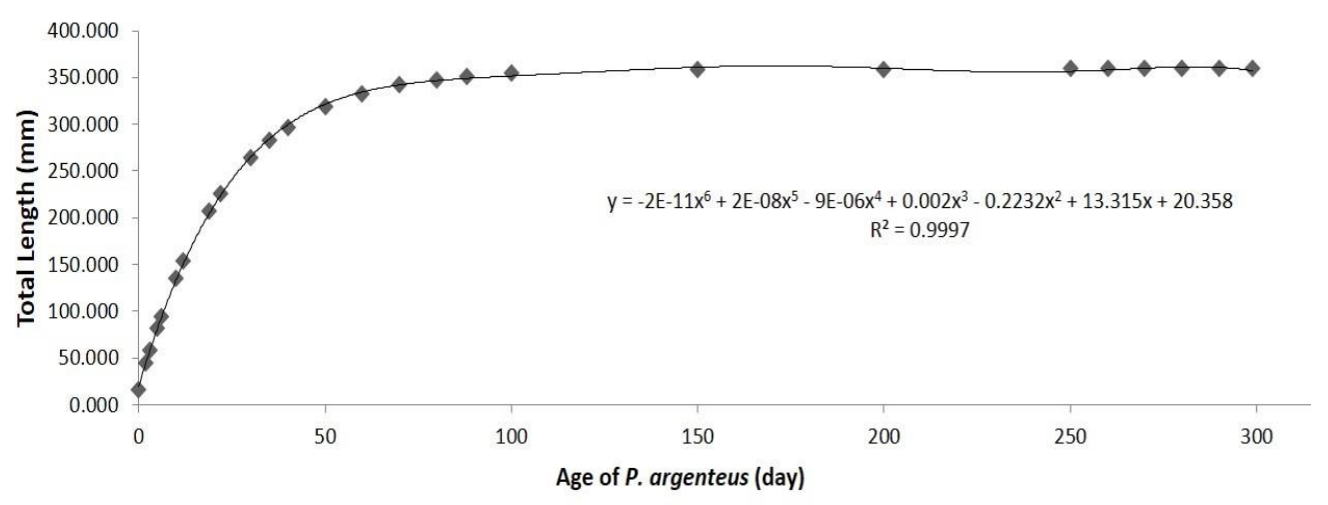

A

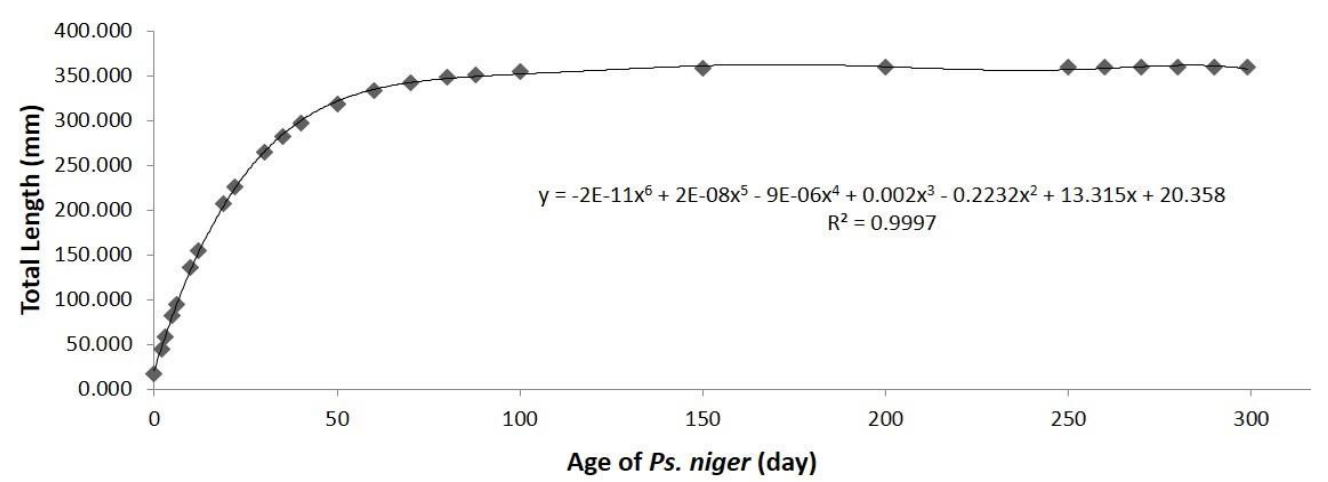

B

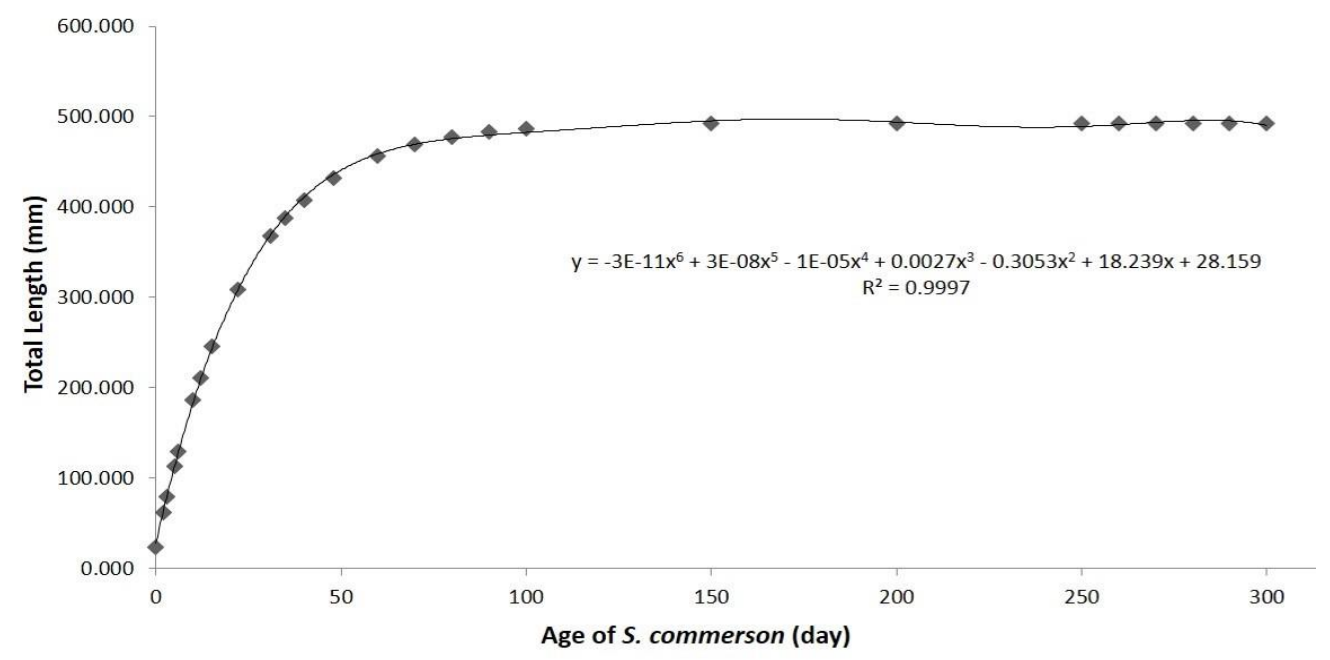

C

Figure 8. Von Bertalanffy growth models. A. P. argenteus; B. Ps. niger; C. S. commerson

Narges et al. (2011) estimated the L $\infty$ of P.argenteus in the northern Persian Gulf to be $339 \mathrm{~mm}$. According to Prihatiningsih et al. (2015), the white pomfret ( $P$. argenteus) in Tarakan waters exhibited a growth coefficient $(\mathrm{k})=0.052 \mathrm{~mm} /$ year; L $\infty$ growth of $372.8 \mathrm{~mm}$, and the value $\left(\mathrm{t}_{0}\right)=0.07 /$ year. Parsa et al (2017) calculated the maximum length $(\mathrm{L} \infty)$ of white pomfret in Java sea to be $=325.5 \mathrm{~mm},\left(\mathrm{t}_{0}\right)=0.54 /$ year, the $\mathrm{k}$ value was $0.3 /$ year. According to Hikmawansyah et al. (2019), the growth of white pomfret in Pangandaran waters characterized by asymptotic length $(\mathrm{L} \infty)$ of $530.4 \mathrm{~mm}$ with a growth coefficient (K) value equal to $0.026 \mathrm{~mm} /$ year. According to Damora et al. (2018), the P. argenteus from In Paloh Waters, West Kalimantan exhibited maximum length of $\mathrm{L} \infty=462 \mathrm{~mm},\left(\mathrm{t}_{0}\right)=0.88 /$ year, the $\mathrm{k}$ value was $0.53 /$ year. According to Ballagh et al. (2006), maximum length (Lo) of mackerel fish originating from the east coast of Queensland, Australia, was estimated to be $1047 \mathrm{~mm}$ (male) and $1248 \mathrm{~mm}$ (male) with a growth rate $(\mathrm{k})$ of $0.075 \mathrm{~mm} /$ year (male) and $0.051 \mathrm{~mm} /$ year (female) with a value $\left(\mathrm{t}_{0}\right)$ of $-0.18 /$ year (male) and $0.39 /$ year (female). 


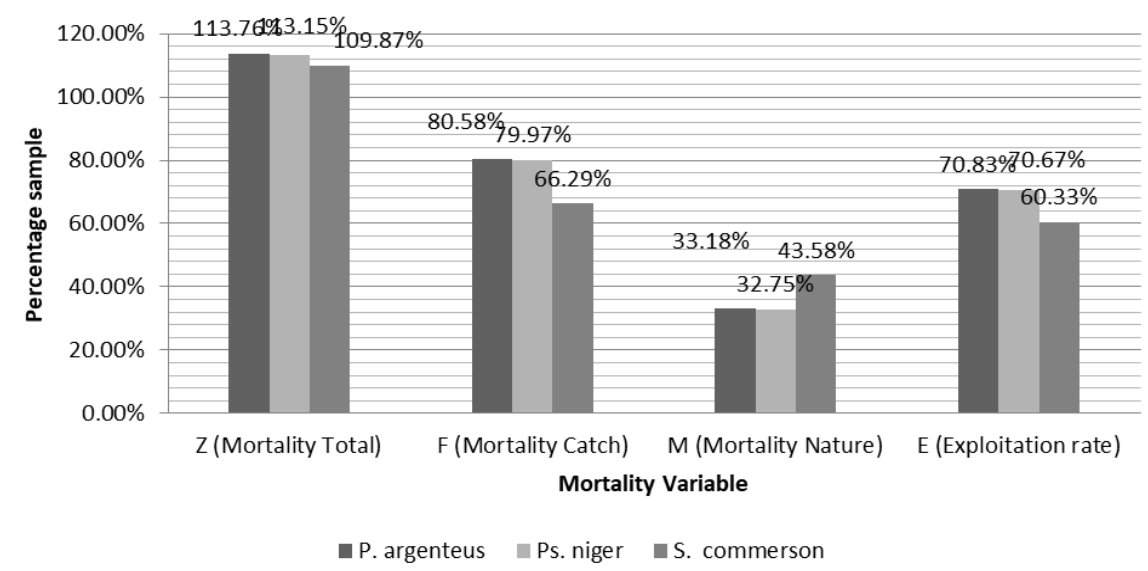

Figure 9. Percentage of total mortality, fishing mortality, natural mortality and exploitation rate of P. argenteus, Ps. niger, and $C$. commerson in the coastal waters of the Indonesian region of Sebatik Island, Indonesia

According to Lessa and Duarte-Neto (2004); Damora and Wagiyo (2012); Damora and Baihaqi (2013) the Lo and $\mathrm{k}$ values are highly dependent on data, including age and growth. The variations in $\mathrm{L} \infty$ and $\mathrm{K}$ values (Pauly 1984 ) in various fishing grounds of white pomfret could be due to the differences in ecology, fish physiological conditions, feeding variability, fishing pressure, and sampling methods (Azis et al. 1992; Biswas 1993; Taghavi Motlagh et al. 2010; Prihatiningsih et al. 2015). This is in accordance with the opinion of Sparre and Venema (1998) whereby they explained that the differences in $\mathrm{K}$ values can also be caused by aquatic environmental conditions. In addition, Widodo (1988) and Ecoutin and Abaret (2005) suggested that the difference in the value of growth parameters is also influenced by the composition of the fish specimens due to variations in method used. If a lot of young fish are caught, the growth coefficient is high and if the older fish are caught, the growth coefficient is low (Widodo 1988). Rumondang (2016) noted that fish can still experience growth (e.g. length) even though the environmental conditions are unfavorable.

Based on the Von Bertalanffy growth model analysis using the orthogonal polynomial type 6 model, the growth of white pomfret can be expressed as $\mathrm{y}=-2 \mathrm{E}-11 \mathrm{x}^{6}+2 \mathrm{E}-$ $08 \mathrm{x}^{5}-9 \mathrm{E}-06 \mathrm{x}^{4}+0.0002 \mathrm{x}^{3}-0.2232 \mathrm{x}^{2}+13.315 \mathrm{x}+20.358$ with $\mathrm{R}^{2}$ of 0.9997 and the correlation value of 0.9999 (Figure 8.A). The orthogonal polynomial equation model type 6 of the black pomfret is expressed as $y=-2 \mathrm{E}-11 \mathrm{x}^{6}+2 \mathrm{E}-08 \mathrm{x}^{5}$ $9 \mathrm{E}-06 \mathrm{x}^{4}+0.002 \mathrm{x}^{3}-0.2232 \mathrm{x}^{2}+13.315 \mathrm{x}+20,358$ with $\mathrm{R}^{2}$ of 0.9997 and a correlation value of 0.9999 (8.B). The orthogonal polynomial equation model type 6 of mackerel was $y=-3 \mathrm{E}-11 \mathrm{x}^{6}+3 \mathrm{E}-08 \mathrm{x}^{5}-1 \mathrm{E}-05 \mathrm{x}^{4}+0.0027 \mathrm{x}^{3}-0.3053 \mathrm{x}^{2}+$ $18.239 \mathrm{x}+28.159$ with an $\mathrm{R}^{2}$ of 0.9997 and a correlation value of 0.9999 (8.C). Correlation analysis revealed that the length and average growth of the three fish species analyzed in this study showed very strong correlation value and in agreement with Sarwono (2013).

\section{Mortality and exploitation rates}

According to Sparre and Vename (1998); Indarjo et al. (2020), mortality rate consists of four components, namely the total mortality, the catch/fishing mortality, the natural mortality, and the exploitation rate. The results of the analysis of mortality and exploitation rates of the three fish species (white pomfret, black pomfret and mackerel) are presented in Figure 9. It was observed that the white pomfret experienced high total mortality rate $(113.76 \%)$. This has been contributed by the high fishing mortality (80.58\%), natural mortality (33.18\%), and exploitation rate (E) of $70.83 \%$. As for black pomfret, it estimated to experience $113.15 \%$ total mortality, $79.97 \%$ fishing mortality, $32.75 \%$ natural mortality, and exploitation rate (E) of $70.67 \%$. Prihatiningsih et al. (2015) recorded total mortality (Z) of white pomfret at $276 \%$, fish mortality (F) of $165 \%$; natural mortality (M) of $111 \%$, and the exploitation rate (E) of 60\%. Parsa et al. (2017) also estimated 155\%/year total mortality, $75 \% / y e a r$ natural mortality, 78\%/year fishing mortality, and exploitation rate of $51 \%$. According to Hikmawansyah et al. (2019), the estimated total mortality rate of white pomfret in Pangandaran waters was $60 \% / y e a r, 364 \%, 304 \%$, and $84 \%$, respectively. The white pomfret from Paloh waters, West Kalimantan (Damora et al. 2018) also exhibited high total mortality (168\%/year), fishing mortality $(121 \%)$, natural mortality (47\%), and exploitation rate of $72 \%$.

Mackerel was estimated to experience $109.87 \%$ total mortality, $66.29 \%$ catch mortality, $43.58 \%$ natural mortality, and $60.33 \%$ exploitation rate. Worrisome, the exploitation rate of each fish species was exceeded the 0.5 (50\%) threshold which indicates that the fish are overfished. The results of current study differ from the study of Yuliana and Nurhasanah (2017) whereby the recorded exploitation rate of mackerel (S. commerson) at Karimunjawa National Park (KNP) to experience low exploitation of 0.29 (under-exploited). This could be that the fish are somehow protected within the part area. Prihatiningsih et al. (2015) reported that the white pomfret population in Tarakan, East Kalimantan to have higher exploitation rate ( $>0.5 /$ year) which indicate that the fish is under tremendous fishing pressure hence it was suggested that better policy for fishery management of the white pomfret in this area should be established. Patterson (1992) 
reported that even at the exploitation level of 0.5 , fishing activity still has the tendency to reduce fish stock abundance. Hence, the author suggested the optimal exploitation level should be maintained at 0.4 in order to prevent stock depletion.

The present study revealed that size distribution of the white pomfret population in Indonesian waters of Sebatik island ranged from 220 to $352.7 \mathrm{~mm}$ whereas the black pomfret population ranged from 220.0 to $377.4 \mathrm{~mm}$. For mackerel, it ranged from 235.4 to $432.0 \mathrm{~mm}$. All the three fish species exhibited negative allometric $(b<3)$ weight and length relationship with moderate to strong correlation. About $50 \%$ and $53.42 \%$ of the white pomfret and black pomfret were characterized by thin body shape. However, $49.40 \%$ of mackerel were characterized by fat body shape. The asymptotic length $(\mathrm{L} \infty)$ for white pomfret was recorded at $359.133 \mathrm{~mm}$; $\mathrm{k}$ value of $0.0427 \mathrm{~mm} /$ year with r-value of 0.9918 and the $t_{0}$ value of $1.11 /$ year. For black pomfret, the L $\infty$ was estimated at $370.22 \mathrm{~mm}$; $\mathrm{k}$ value of $0.043 \mathrm{~mm} /$ year with $\mathrm{r}$-value at 0.9919 and the $\mathrm{t}_{0}$ value of $1.104 /$ year. For mackerel, the L $\infty$ value was estimated at $492.724 \mathrm{~mm}$, k-value of $0.0246 \mathrm{~mm} /$ year with $\mathrm{r}$-value of 0.9634 and the $t_{0}$ value of $1.322 /$ year. The mortalities $(\mathrm{Z}, \mathrm{F}$ and $\mathrm{N}$ ) and exploitation rate (E) for white pomfret were recorded at $113.76 \%, 80.58 \%, 33.18 \%$ and $70.83 \%$, respectively. For black pomfret, it recorded $113.15 \%$, $79.97 \%, 32.75 \%$ and $70.67 \%$, respectively. For mackerel, it recorded $109.87 \%, 66.29 \%, 43.58 \%$ and $60.33 \%$, respectively. The high exploitation rate $(>50 \%)$ and fishing mortality $(>60 \%)$ of all the fish species analyzed in this study indicate that there is a sign of overfishing of these fish resources in the coastal waters of Sebatik island. Hence, sustainable fishing management such as fishing restriction to small-sized and first mature fish, close fishing season and strict requirement for fishing permit, is timely needed to prevent depletion of these fishery important species in the coastal waters of Sebatik island.

\section{ACKNOWLEDGEMENTS}

The author would like to express his gratitude to fishermen who catch pomfret gill nets, namely Bahar, Surianto and Abdul Salam who are in the Sebatik area, Indonesia.

\section{REFERENCES}

AliT, S., 2001. Effects of shrimp trawlers on the fisheries status and environment of the Northwestern Arabian Gulf. Acta Ichthyol Piscat 313 (2): 77-86.

Azis KA, Muchsin I, Boer M. 1992. Kajian Dinamika Populasi Ikan-ikan Niaga Utama di Perairan Pantai Barat Bengkulu. [Laporan Penelitian]. Fakultas Perikanan, Institut Pertanian Bogor, Bogor. [Indonesian]

Ballagh AC, Begg GA, Mapleston A, Tobin A. 2006. Growth trends of Queensland east coast Spanish mackerel (Scomberomorus commerson) from otolith back-calculations. Mar Freshw Res 57: 383 393.

Biswas SP. 1993. Manual of Methods in Fish Biology. SouthAsia Publishers, Pvt. Ltd, NewDelhi, India.
Badan Pusat Statistik. Kabupaten Nunukan. 2017. Kabupaten Nunukan Dalam Angka Tahun 2017. BPS Kabupaten Nunukan, Nunukan. https://nunukankab.bps.go.id/publication/2017/08/11/e4779772d00ca bf511b60ab9/kabupaten-nunukan-dalam-angka-2017.html

Damora A, Wagiyo K. 2012. Population parameters of Spilgler's Mullet (Valamugil speigleri) as an intensity indicator of utilization of estuaries waters resources in Pemalang, Central Java. Bawal 4 (2): 91 96. [Indonesian]

Damora A, Baihaqi. 2013. Size distribution and population parameters of Yellowfin Tuna (Thunnus albacares) in Banda Sea. Bawal 5 (1): 59 65. [Indonesian]

Damora A, Ariyogagautama D, Wahju RI, Susanto H, Wang J. 2018. Short communication: Growth and mortality rate of black pomfret Parastromateus niger (Bloch, 1795) and black pomfret Pampus argenteus (Euphrasen, 1788) in Paloh Waters, West Kalimantan, Indonesia. Biodiversitas 19 (6): 2247-2251. DOI: 10.13057/Biodiv/D190633.

Ecoutin JM, Albert JJ, Trape S. 2005. Length-weight relationships for the population of a relatively undisturbed tropical estuary: The Gambia. Fish Res 72 (2-3): 347-351. DOI: 10.1016/j.fishres.2004.10.007.

Effendie MI. 2002. Biologi Perikanan. Yayasan Pustaka Nusatama, Yogyakarta.

Firdaus M, Salim G, Cahyadi J, Weliyadi E, Bintoro G. 2020. Model and nature of growth of red snapper fish (Lutjanus argentimaculatus (Forsskål, 1775)) fishing catch of bottom fish pots in Bunyu waters, North Kalimantan. AACL Bioflux 13 (3): 1410-1421.

Firdaus M, Lelono TD, Saleh R, Bintoro G, Salim G. 2018. The expression of the body shape in fish species Harpadon nehereus (Hamilton, 1822) in the waters of juata laut, Tarakan City, North Kalimantan. AACL Bioflux 11 (3): 613-624 DOI: 10.5281/zonodo.1250264.

Firdaus M, Salim G. 2011. Mengkaji populasi ikan puput (Ilisha elongata) yang berasal dari perairan Kota Tarakan. Harpodon 4 (1): 46-53. DOI: 10.35334/harpodon.v4i1.62.

Gupta BK, Sarkar UK, Bhardwaj SK, Pal A. 2011. Condition factor, length-weight and length-weight relationships of an endangered fish Ompok pabda (Hamilton 1822) (Siluriformes: Siluridae) from the River Gomti, a tributary of the River Ganga, India. J Appl Ichthyol 27 (3): 962-964. DOI: 10.1111/j.1439-0426.2010.01625.x

Hamid MA, Mansor M, Azizah SMN. 2015. Length-weight relationship and condition factor of fish population in Temengor Reservoir: Indication of environmental health. Sains Malaysiana 44 (1): 61-66.

Hashemi SAR, Safikhani H, Vahabnezhad A. 2012. Growth, mortality parameters and exploitation rate of silver pomfret (Pampus argenteus Euphrasen, 1788) in Northwest of Persian Gulf (Khuzestan Coastal Waters, Iran). American-Eurasian J Agric Environ Sci 12 (8): 10951101. DOI: 10.5829/idosi.aejaes.2012.12.08.66127

Hikmawansyah Y, Andriani Y, Khan AMA, Dewanti LP. 2019. Stock estimates of white pomfret (Pampus argenteus) based on length and weight data in Pangandaran Waters. Asian J Fish Aquatic Res 5 (1-2): $1-13$.

Indarjo A, Salim G, Zein M, Soejarwo PA, Nugraeni CD, Bija S, Pham YTH. 2020. Characteristics of Von Bertalanffy growth, allometric, condition index and mortality of Periophthalmus barbarus in Mangrove and Bekantan Conservation Area (KKMB), Tarakan, North Kalimantan. Indon J Mar Sci 25 (1): 31-38. DOI: 10.14710/ik.ijms.25.1.31-38.

Indarjo A, Salim G, Zein M, Septian D, Bija S. 2020. The population and mortality characteristics of mangrove crab (Scylla serrata) in the mangrove ecosystem of Tarakan City, Indonesia. Biodiversitas 21 (8): 3856-3866. DOI: 10.13057/biodiv/d210855.

Indarjo A, Salim G, Amir F, Supriadi S, Soejarwo PA, Nugraeni CD, Prakoso LY, Ambariyanto A, Firdaus M, Ransangan J. 2020. Growth Characteristics layur fish Lepturacanthus savala in Juata Waters, Tarakan, Indonesia. Indon J Mar Sci 25 (3): 127-134. DOI: 10.14710/ik.ijms.25.3.127-134.

Khaerudin. 2006. Proporsi Hasil Tangkap Sampingan Jaring Arad (Mini Trawl) yang Berbasis di Pesisir Utara, Kota Cirebon. Skripsi. Institute Pertanian Bogor, Bogor. [Indonesian]

Laga, A, Salim, G, Wiharyanto, D. 2017. Analysis Model Allometry Growth And Index Condition Fish of Bawal (Pampus argenteus) Originating In Coastal Areas The Southern Town of Tarakan. Universitas Borneo Tarakan, Tarakan.

Shu LM, Qiu YS. 2005. Estimation of growth and mortality parameters for Pampus argenteus in Pearl River Estuary and adjacent waters. J Fish China 29 (2):193-197. 
Lee DW, Kim YM. 1992. Stock assessment of silver pomfret, in Korean waters Bull Natl Fish Res Dev Agency Korea 46: 41-45.

Le Cren CD. 1951. The length-weight relationship and seasonal cycle in gonad weight and condition in perch, Perca fluviatilis. J Anim Ecol 20: 201-219. DOI: $10.2307 / 1540$

Lessa R, Duarte-Neto P. 2004. Age and growth of yellowfin tuna (Thunnus albacares) in the Western Equatorial Atlantic, Using Dorsal Fin Spines. Fish Res 69 (2): 157-170. DOI: 10.1016/j.fishres.2004.05.007

Mommsen TP. 1998. Growth and metabolism. In: Evans DH (eds). The Physiology of Fishes. CRC Press, New York.

Mohammadkhani H, Shirangi SA. 2013. Investigating the frequency of three species of Perciformes in Oman Sea (Chabahar Coasts) in 2000. Iran J Fish Sci 6 (3): 1-12.

Mohammadi GH, Gholami R, Alvi A, Moghamesi S, Ofipor M. 2005. Study of some biological characteristics of economical fishes (Tiger tooth Croacher, Silver pomfret, Yellowfin sea bream, Hilsa shad, Indo-pacific king mackerel, Narrow-barred Spanish, etc.) in the coastal waters of the Persian Gulf, South of Iran. Aquaculture Fishery Research Center, Ahwaz. Iran.

Mohamed ARM, Resean AK, Hashim AA. 2008. The status of Pampus argenteus population after exposure to adverse ecological consequences between 1980 and 2005 in Iraq marine waters, Northwest Arabian Gulf. Proceedings of the 1st International Conference on Agricultural Biological Science 1: 59.

Morgan GR. 1985. Stock assessment of silver pomfret Pampus argenteus in Kuwaiti waters. J Mar Sci 42 (1): 3-10. DOI: 10.1093/icesjms/42.1.3

Mustafa, G.M. 1993. ELEFAN based growth parameters of white pomfret Pampus argenteus from the Bay of Bengal. Bangladesh J Zool 21 (1): 143-149.

Mustafa MG. 1999 Population dynamics of penaeid shrimps and demersal finfishes from Traud Fishery in the Bay of Bengal and Implication for the management. [Dissertation], Bangladesh: University of Dhaka, Dhaka.

Narges A, Preeta K, Jasem M, Gholam E, Vahid Y. 2011. Stock assessment of silver pomfret Pampus argenteus (Euphrasen, 1788) in the Northern Persian Gulf. Turkish J Fish Aquatic Sci 11: 63-68. DOI: $10.4194 /$ trjfas.2011.0109

Noegroho T, Hidayat T, Chodriyah U, Patria MP. 2018. Reproductive biology of Spanish Mackerel (Scomberomorus commerson Lacepede, 1800) at Kwandang Bay Waters, Sulawesi sea. Bawal 10 (1): 69-84.

Nukpi, M., 1996. Survey biology Silver pomfret ( $P$. argenteus) in Khuzestan province. South of Iran. Aquaculture Fishery Research Center, Ahwaz, Iran. [Farsi]

Nugraeni CD, Salim G, Haryono MG, Indarjo A, Zein M. 2019. Analisis bionutrition ikan bawal (Pampus sp.) yang berasal dari perairan Kota Tarakan. Prosiding Seminar Nasional Sains Lingkungan dan Pendidikan Ke-VI. Fakultas Keguruan dan Ilmu Pendidikan Universitas Borneo Tarakan. Prosiding Seminar Nasional Salingdidik "Sains Lingkungan dan Pendidikan" Volume 4 Tahun 2019. DOI: 10.13140/RG.2.2.15475.89124. [Indonesian]

Parsamanesh A, Shalbaf MR, Eskandari Gh, Kashi MT. 2003. Stock Assessment of Khouzestan Fishes (1994-2001). Khouzestan Fisheries Research Centre, Iranian Fisheries Research Organization (IFRO), Iran.

Parsa M, Khoshdarehgi MM, Nekuro A, Pouladi M. 2017. Population dynamics parameters of Silver Pomfret Pampus argenteus in Iranian waters of the northern Persian Gulf and Oman Sea. Biodiversitas 18 (2): 633-638. DOI: 10.13057/biodiv/d180226
Patterson K. 1992. Fisheries for small pelagic species: An empirical approach to management targets. Rev Fish Biol Fisher 2: 321-338.

Pauly D. 1984. Fish Population Dynamics in Tropical Waters: A Manual for Use with Programmable Calculators (Vol. 8). WorldFish, Malaysia.

Pemerintah Kabupaten Nunukan. 2002. Pengembangan Pembangunan Kawasan Kabupaten Nunukan. Provinsi Kalimantan Utara. [Indonesian]

Prasetiyo SL, Baskoro MS, Yusfiandayani R, Pahlevi R. 2020. Performance analysis of small pelagic fishing unit in Tawang fishing port, Kendal Regency. IOP Conf Ser Earth Environ Sci 404: 012030. DOI: 10.1088/1755-1315/404/1/012030

Prihatiningsih, Mukhlis N, Hartati ST. 2015. Population parameters of white pomfret (Pampus argenteus) in Tarakan Waters, East Kalimantan. Bawal 7 (3): 165-174.

Randall, John E. 1995. A review of the triplefin fishes (Perciformes: Blennioidei: Tripterygiidae) of Oman, with descriptions of two new species of Enneapterygius. Revue française d'Aquariologie Herpétologie 22 (1-2): 27-34.

Ricker, W.E. 1973. Linear regression in fisheries research. J Fish Res Board Can 30: 409-434.

Rumondang R. 2016. Mortalitas dan tingkat eksploitasi ikan brek (Barbonymus balleroides Val. 1842) di Sungai Serayu Kabupaten Banjarnegara, Jawa Tengah. Agricola 6 (1): 1-12. DOI: 10.35724/Ag.V6i1.391

Salari M. 1996. Studies on the Biology of Silver Pomfret, Pampus argenteus (Euphrasen) from Musa Estuaries of Iran. [Dissertation]. Chamran University, Ahvaz. [Iranian]

Salim G. 2015. Analisis pertumbuhan allometri dan indeks kondisi Caesio cunning didapatkan dari hasil tangkapan nelayan Kota Tarakan. Jurnal Harpodon Borneo 8 (1): 35-42. DOI: 10.35334/harpodon.v8i1.125. [Indonesian]

Salim G. 2013. Nilai indeks kondisi dari ikan Siganus javus berdasarkan hasil tangkapan nelayan di Perairan Juata Kota Tarakan. Jurnal Harpodon Borneo 8 (1): 37-42. DOI: 10.35334/harpodon.v6i1.99. [Indonesian]

Sari MAP, Sujarwoto. 2019. Ship sinking policy and socioeconomic welfare: A case study in Sebatik Island, Nunukan District, North Kalimantan Province. Jurnal Borneo Administrator 15 (3): 275-292.

Sarwono J. 2013. Statistik Terapan untuk Riset Skripsi, Tesis dan Disertasi. Penerbit Elexmedia Komputindo, Jakarta. [Indonesia]

Sparre P, Venema SC. 1998. Introduction to Tropical Fish Stock Assessment Volume 1. FAO Fisheries Technical Paper, Rome.

Walker RD, Carlander KD. 1970. Effects of Population Density upon Channel Catfish in Enclosures. Proc Iowa Acad Sci 77 (1): 15.

Weng JS, Yu SF, SinLo Y, ChiehShiao J, AnLee M, MingLiu K, HanHuang H, ChenWang Y, JingWu L. 2020. Reproductive biology of the narrow-barred Spanish mackerel (Scomberomorus commerson) in the Central Taiwan Strait, Western Pacific. Deep Sea Res Part II: Trop Stud Oceanograph 175: 104755. DOI: 10.1016/j.dsr2.2020.104755

Widodo J. 1988. Population Dynamics and Management of Ikan Layang, Scad Mackerel, Decapterus spp. (Pisces: Carangidae) in the Java Sea. [Dissertation]. University of Washington, Seattle, USA.

Yuliana E, Nurhasanah N. 2017. Laju eksploitasi ikan tenggiri dan tongkol di Kawasan Konservasi Taman Nasional Karimunjawa. Jurnal Matematika Sains dan Teknologi 18 (1): 44-55. DOI: 10.33830/jmst.v18i1.176.2017. [Indonesian] 